\title{
Erratum: A phylogenomic and molecular signature based approach for characterization of the Phylum Spirochaetes and its major clades: proposal for a taxonomic revision of the phylum
}

\section{Radhey S. Gupta*, Sharmeen Mahmood and Mobolaji Adeolu}

Department of Biochemistry and Biomedical Sciences, McMaster University, Hamilton, ON, Canada

*Correspondence: gupta@mcmaster.ca

Edited by:

Eric Altermann, AgResearch Ltd, New Zealand

Reviewed by:

Brian Tindall, DSMZ, Germany

Keywords: spirochaetes phylogeny and taxonomy, molecular signatures, spirochaetales, spirochaetaceae, borreliaceae, brachyspirales, leptospirales, conserved signature indels

\section{A commentary on}

A phylogenomic and molecular signature based approach for characterization of the phylum Spirochaetes and its major clades: proposal for a taxonomic revision of the phylum

By Gupta, R. S., Mahmood, S., and Adeolu, M. (2013) Front Microbiol. 4:217. doi: 10.3389/fmicb.2013.00217

Dr. Aharon Oren, the Editor and one of the List Editors of the Journal IJSEM, has informed us of a few minor errors in the protologues present in this publication which would prevent valid publication of the proposed names. The nomenclatural types we proposed for the new orders Brachyspirales ord. nov., Brevinematales ord. nov. and Leptospirales ord. nov. and the emended description we proposed for the order Spirochaetales (Buchanan, 1917) (Approved Lists 1980) were not in accordance with Rule 21a of the Bacteriological code and the etymology of the names of the family Borreliaceae fam. nov. and the orders Brachyspirales ord. nov., Brevinematales ord. nov. and Leptospirales ord. nov. were not in accordance with Rule 9 and Recommendation 6 of the Bacteriological code (Lapage et al., 1992). Hence, we are resubmitting revised protologues of the emendations and newly proposed taxa, correcting the minor errors present in the original submission.

\section{EMENDED DESCRIPTION OF THE} ORDER Spirochaetales Buchanan, 1917 (APPROVED LISTS 1980)

The order contains two families, Spirochaetaceae and Borreliaceae.
Organisms are helical or coccoid, $0.1-75 \mu \mathrm{m}$ in diameter and $3.5-250 \mu \mathrm{m}$ in length. Cells do not have hooked ends. Cells may possess flagella. Periplasmic flagella overlap in the central region of the cell. The diamino acid component of the peptidoglycan is L-ornithine. Anaerobic, facultatively anaerobic, or microaerophilic. Organisms are chemoorganotrophic and utilize carbohydrates or amino acids as carbon and energy sources. Both free living and host associated members. The $\mathrm{G}+\mathrm{C}$ content of the DNA is $27-66(\mathrm{~mol} \%)$. The type genus is Spirochaeta Ehrenberg 1835 (Approved Lists 1980) Skerman et al. (1980).

Organisms from this order are distinguished from all other bacteria examined to date by the conserved signature indels described in this report in the following proteins: alanyl-tRNA synthetase, phosphoribosylpyrophosphate synthetase, SecY preprotein translocase, peptide chain release factor 2, DNA mismatch repair protein MutS, and DNA mismatch repair protein MutL.

\section{EMENDED DESCRIPTION OF THE}

\section{FAMILY Spirochaetaceae}

Swellengrebel, 1907 (APPROVED LISTS 1980) EMEND. Abt et al. (2013)

The family contains seven genera, Clevelandina, Diplocalyx, Hollandina, Pillotina, Sphaerochaeta, Spirochaeta, and Treponema. Organisms are helical or coccoid, $0.1-75 \mu \mathrm{m}$ in diameter and $5-250 \mu \mathrm{m}$ in length. Cells do not have hooked ends. Cells may possess flagella. Periplasmic flagella overlap in the central region of the cell. Cells can be anaerobic or facultatively anaerobic. The diamino acid component of the peptidoglycan is L-ornithine. Organisms are chemoorganotrophic and utilize carbohydrates or amino acids as carbon and energy sources. Both free living and host associated members. The $\mathrm{G}+\mathrm{C}$ content of the DNA is $36-66(\mathrm{~mol} \%)$. The type genus is Spirochaeta Ehrenberg 1835 (Approved Lists 1980) Skerman et al. (1980).

Organisms from this family are distinguished from all other bacteria examined to date by the conserved signature indels described in this report in the following proteins: 6phosphofructokinase (pyrophosphate), bifunctional Hpr kinase/phosphatase and 30 S ribosomal protein S13.

\section{DESCRIPTION OF Borreliaceae}

fam. nov.

Borreliaceae (Bor.re'li.a'ce.ae. N.L. fem. n. Borrelia type genus of the family; -aceae ending to denote a family; N.L. fem. pl. n. Borreliaceae the family whose nomenclatural type is the genus Borrelia).

The family contains two genera Borrelia and Cristispira. Organisms are helical, $0.2-3 \mu \mathrm{m}$ in diameter and 3$180 \mu \mathrm{m}$ in length. Cells do not have hooked ends. Periplasmic flagella overlap in the central region of the cell. Cells are motile, host-associated and microaerophilic. The diamino acid component of the peptidoglycan is L-ornithine. Organisms are chemoorganotrophic and utilize carbohydrates or amino acids as carbon and energy sources. The $\mathrm{G}+\mathrm{C}$ content of the DNA is 27-32 (mol\%). The type genus is Borrelia 
(Swellengrebel, 1907) (Approved Lists 1980).

Organisms from this family are distinguished from all other bacteria examined to date by the conserved signature indels described in this report in the following proteins: phosphofructokinase, $50 \mathrm{~S}$ ribosomal protein L4, tRNA pseudouridine 55 synthase, translation elongation factor-Tu, histidyl-tRNA synthetase, seryl-tRNA synthetase, spoiiij-associtated protein, nicotinate phosphoribosyltransferase, ribose 5-phosphate isomerase, ribonuclease $\mathrm{Z}$, hypothetical protein BGAFAR04_0762, signal recognition particle subunit FFH/SRP54, hypothetical protein BSV1_0075, aspartyl/glutamyltRNA amidotransferase subunit A, ribosomal RNA methyltransferase and a LysM domain/M23/M37 peptidase domain protein.

\section{DESCRIPTION OF Brachyspirales}

\section{ord. nov.}

Brachyspirales (Bra.chy.spi.ra'les. N.L. fem. n. Brachyspira type genus of the order; suff. -ales ending to denote an order; N.L. fem. pl. n. Brachyspirales the order whose nomenclatural type is the genus Brachyspira).

The order contains one family, Brachyspiraceae. Organisms are helical, $0.2-0.4 \mu \mathrm{m}$ in diameter and $2-11 \mu \mathrm{m}$ in length. Cell ends may be blunt or pointed and do not have hooked ends. Periplasmic flagella overlap in the central region of the cell. Cells are motile, host-associated and obligately anaerobic and aerotolerant. The diamino acid component of the peptidoglycan is L-ornithine. Organisms are chemoorganotrophic and utilize monosaccharides, disaccharides, the trisaccharide trehalose, and amino sugars as carbon and energy sources. The $\mathrm{G}+\mathrm{C}$ content of the DNA is $24-28$ (mol\%). The type genus is Brachyspira (Hovind-Hougen, 1983).

Organisms from this order are distinguished from all other bacteria examined to date by the conserved signature indels described in this report in the following proteins: flagellar hook-associated protein FlgK, DNA polymerase I, valyltRNA synthetase, ATP-dependent protease La and glutamyl-tRNA amidotransferase subunit B.

\section{EMENDED DESCRIPTION OF THE FAMILY Brachyspiraceae Paster, 2012a}

The family contains one genus, Brachyspira. The description of the family Brachyspiraceae (Paster, 2012a) is the same as that of the order Brachyspirales ord. nov. The type genus is Brachyspira (Hovind-Hougen, 1983).

\section{DESCRIPTION OF Brevinematales}

ord. nov.

Brevinematales (Bre.vi.ne.ma.ta'les. N.L. neut. n. Brevinema type genus of the order; suff. -ales ending to denote an order; N.L. fem. pl. n. Brevinematales the order whose nomenclatural type is the genus Brevinema).

The order contains one family, Brevinemataceae. The description of this order is the same as that of the family Brevinemataceae (Paster, 2012b). The type genus is Brevinema (Defosse et al., 1995).

\section{DESCRIPTION OF Leptospirales}

ord. nov.

Leptospirales (Lep.to.spi.ra'les. N.L. fem. n. Leptospira type genus of the order; suff. -ales ending to denote an order; N.L. fem. pl. n. Leptospirales the order whose nomenclatural type is the genus Leptospira).

The order contains one family, Leptospiraceae. Organisms are helical, $0.1-0.3 \mu \mathrm{m}$ in diameter and $2-11 \mu \mathrm{m}$ in length. Cells have hooked ends. Periplasmic flagella do not overlap in the central region of the cell. Cells are motile. The diamino acid component of the peptidoglycan is $\alpha, \varepsilon$-diaminopimelic acid. Obligately aerobic or microaerophilic. Organisms are chemoorganotrophic and utilize long-chain fatty acids or long-chain fatty alcohols as carbon and energy sources. Both free living and hostassociated members. The $\mathrm{G}+\mathrm{C}$ content of the DNA is $33-55$ ( $\mathrm{mol} \%)$. The type genus is Leptospira (Noguchi, 1917) (Approved Lists 1980).

Organisms from this order are distinguished from all other bacteria examined to date by the conserved signature indels described in this report in the following proteins: 50S Ribosomal protein L14, 30S Ribosomal protein S2, alanyl-tRNA synthetase, flagellar basal-body rod protein FlgG, and flagellar filament core protein FlaB.

\section{EMENDED DESCRIPTION OF THE FAMILY Leptospiraceae Hovind- Hougen, 1979 (APPROVED LISTS 1980) EMEND. Levett et al. (2005)}

The family contains three genera, Leptonema, Leptospira, and Turneriella. The description of the family Leptospiraceae (Hovind-Hougen, 1979) (Approved Lists 1980) emend. (Levett et al., 2005) is the same as that of the order Leptospirales ord. nov. The type genus is Leptospira (Noguchi, 1917) (Approved Lists 1980).

\section{REFERENCES}

Abt, B., Göker, M., Scheuner, C., Han, C., Lu, M., Misra, M., et al. (2013). Spirochaetaceae Swellengrebel 1907 (Approved Lists 1980) emend. Abt et al. 2012. In Notification of changes in taxonomic opinion previously published outside the IJSEM, List no 17, Int. J. Syst. Evol. Microbiol. 63, 8-9. doi: 10.1099/ijs.0.049320-0

Buchanan, R. E. (1917). Studies in the nomenclature and classification of the bacteria: II. The primary subdivisions of the schizomycetes. J. Bacteriol. 2, 155.

Defosse, D. L., Johnson, R. C., Paster, B. J., Dewhirst, F. E., and Fraser, G. J. (1995). Brevinema andersonii gen. nov., sp. nov., an Infectious Spirochete Isolated from the Short-Tailed Shrew (Blarina brevicauda) and the White-Footed Mouse (Peromyscus leucopus). Int. J. Syst. Bacteriol. 45, 78-84. doi: 10.1099/0020771345-1-78

Hovind-Hougen, K. (1979). Leptospiraceae, a New Family to Include Leptospira Noguchi 1917 and Leptonema gen. nov. Int. J. Syst. Bacteriol. 29, 245-251. doi: 10.1099/00207713-29-3-245

Hovind-Hougen, K. (1983). Brachyspira gen. nov. In validation of the publication of new names and new combinations previously effectively published outside the IJSB, List No 12, Int. J. Syst. Evol. Microbiol. 33, 896-897.

Lapage, S. P., Sneath, P. H. A., Lessel, E. F., Skerman, V. B. D., Seeliger, H. P. R., and Clark, W. A. (1992). International Code of Nomenclature of Bacteria: Bacteriological Code, 1990 Revision, Washington, DC: ASM Press International Union of Microbiological Societies.

Levett, P., Morey, R., Galloway, R., Steigerwalt, A., and Ellis, W. (2005). Reclassification of Leptospira parva Hovind-Hougen et al. 1982 as Turneriella parva gen. nov., comb. nov. Int. J. Syst. Evol. Microbiol. 55, 1497-1499. doi: 10.1099/ijs.0.63 088-0

Noguchi, H. (1917). Spirochaeta icterohaemorrhagiae in American wild rats and its relation to the Japanese and European strains: first paper. J. Exp. Med. 25, 755-763. doi: 10.1084/jem.25. 5.755

Paster, B. J. (2012a). Brachyspiraceae fam. nov. In list of new names and new combinations previously effectively, but not validly, published, List no 144 , Int. J. Syst. Evol. Microbiol. 62, 473-475. doi: 10.1099/ijs.0.041269-0 
Paster, B. J. (2012b). Brevinemataceae fam. nov. In List of new names and new combinations previously effectively, but not validly, published, List no 144, Int. J. Syst. Evol. Microbiol. 62, 473-475. doi: 10.1099/ijs.0.04 1269-0

Skerman, V. B. D., McGowan, V., and Sneath, P. H. A. (1980). Approved lists of bacterial names. Int. J. Syst. Bacteriol. 30, 225-420. doi: 10.1099/00207713-30-1-225

Swellengrebel, N. H. (1907). Sur la cytologie comparée des spirochètes et des spirilles. Ann. Inst. Pasteur (Paris) 21, 562-586.

Received: 16 September 2013; accepted: 13 October 2013; published online: 31 October 2013.

Citation: Gupta RS, Mahmood S and Adeolu M (2013)

Erratum: A phylogenomic and molecular signature based approach for characterization of the Phylum Spirochaetes and its major clades: proposal for a taxonomic revision of the phylum. Front. Microbiol. 4:322. doi: 10.3389/fmicb.2013.00322
This article was submitted to Evolutionary and Genomic Microbiology, a section of the journal Frontiers in Microbiology.

Copyright (C) 2013 Gupta, Mahmood and Adeolu. This is an open-access article distributed under the terms of the Creative Commons Attribution License (CC BY). The use, distribution or reproduction in other forums is permitted, provided the original author(s) or licensor are credited and that the original publication in this journal is cited, in accordance with accepted academic practice. No use, distribution or reproduction is permitted which does not comply with these terms. 